\title{
PREVALENCE OF CONTRACEPTIVE USE AMONG KENYA COAST NATIONAL POLYTECHNIC STUDENTS
}

\author{
Kailong J. M. ${ }^{1}$ \\ ${ }^{1}$ Assistant lecturer, \\ Department of medical sciences, \\ School of pure and health sciences, \\ Technical University of Mombasa, \\ Kenya
}

\author{
Adem A, \\ ${ }^{2}$ Lecturer, \\ Department of mathematics and Physics, \\ School of pure and health sciences, \\ Technical University of Mombasa, \\ Kenya.
}

Article DOI: https://doi.org/10.36713/epra5664

\begin{abstract}
The study purpose of the study was to determine the prevalence of emergency contraceptive use among the Kenya Coast National Polytechnic. The objective of the study was to establish the level of contraceptive use, student knowledge on contraceptives and accessibility of contraceptives. A descriptive cross sectional study design was employ to collect both qualitative and quantitative data. Data was collected from sample size of 196 calculated using Fisher's formula. Data was collected using both structured questionnaires and interviews. The collected data was analyzed using SPPS version 20 and presented using tables and pie charts. About 32\% of the respondents were using contraceptive, 99\% had knowledge on contraceptives and $77 \%$ could access contraceptives within their neighborhood. Bivariate analysis findings show that residence $(p=0.000)$, course $(P=0.000)$, usage of contraceptive $(p=0.000)$ and availability at a nearby facility $(p=0.009)$ to statistically significant in contraceptive use. The study recommends that the respondents need more knowledge on various contraceptive options, support from both institution of learning as well as parents on safe sex practices and reliable provision of contraceptives
\end{abstract}

KEY WORDS: Contraceptives, teenagers, accessibility

\section{INTRODUCTION}

Emergency contraceptives are medicines taken to reduce the risk of pregnancy within a few days after sexual intercourse during which contraceptives fail or were not used (WHO, 2012). Emergence contraceptives pills are taken after unprotected sexual intercourse or breakage of condom (Sedgh et al; 2007). The common forms of emergency contraceptive are levonorgestrel and Birth control pills (WHO, 2004). Globally, emergency contraceptives can prevent up to over $95 \%$ of pregnancies when taken within five days after intercourse (WHO, 2012).

In Africa $24 \%$ women of reproductive age have the highest unmet need for contraception rates (WHO, 2004). In Uganda, NGOS are trying to make contraceptives more available in rural areas. According to study that was done by Nwachukwu and Obese in
Nigeria 2008, modern birth control method were used by $30 \%$ respondents in Sub-Saharan Africa (Obi et al; 2008).

In Kenya, the prevalence of contraceptive use has increased since $1970 \mathrm{~s}$, at which time only $7 \%$ of married women of reproductive age used any method of family planning (Raymond et al; 2011). By 1988, this figure has grown to nearly $40 \%$ as contraceptives use had increased, Kenya's total fertility rate has dropped from more than eight children (Singhs et al; 2010).

The purpose of this study was to systematically review the prevalence of emergency contraceptive use among college students. Kenya coast national polytechnic is a national polytechnic with over 5000 student population. 


\section{OBJECTIVES}

\section{Broad objective}

To determine the prevalence of emergency contraceptive use among Kenya Coast National Polytechnic students

\section{Specific objectives}

a) To establish the level of emergence contraceptive use

b) To know the knowledge of students on contraceptives

c) To determine the accessibility of contraceptives

\section{METHODOLOGY}

The study employed a descriptive cross sectional study design to collect both quantitative and qualitative data from the respondents. The target populations were female students who are bonafide students of the college with college identity card

\section{STUDY SITE}

The study was conducted at Kenya coast national polytechnic. The college is located in Majengo Kisauni road, Mombasa County, Mvita Sub County. The institutions offer variety of courses ranging from certificate, diploma and higher national diploma. The is made up of ten departments, namely; Business management, Secretarial and language, Medical science, Journalism, Catering, Fashion and design, Information technology, Hospitality, Applied science, Mechanical, building and electrical engineering

\section{SAMPLING}

The study employed cluster random sampling was used to come up with a sample frame from the ten departments. Then simple random sampling was used to recruit the subjects into the study. Structured questionnaires were administered to the respondents as well as interviews conducted on two selected subjects from each department. All study subjects were taken through the purpose of the study and signed a written informed consent before taking part

\section{SAMPLE SIZE}

The sample size was determined using Fisher's formula (Mugenda, 1999)

$\mathrm{n}=\frac{\mathrm{Z}^{2} \mathrm{qp}}{\mathrm{d}^{2}}$

$\mathrm{n}=$ desire sample size

$\mathrm{z}=$ standard normal deviation (1.96)

$\mathrm{p}=$ anticipated population proportion

$(15 \%)$

$$
\begin{aligned}
& \mathrm{q}=1-\mathrm{p} \\
& \mathrm{d}=\text { allowable error } \\
& \mathrm{n}=\frac{(1.92)^{2}(0.15)(0.85)}{(0.05)^{2}} \\
& =196
\end{aligned}
$$

\section{DATA MANAGEMENT}

The collected data was edited, transcript, coded and entered into SPSS version 21 software for analysis. The study findings were presented using tables and pie charts 


\section{RESULTS}

Figures

\section{CONTRACEPTIVES USE EXTENT}

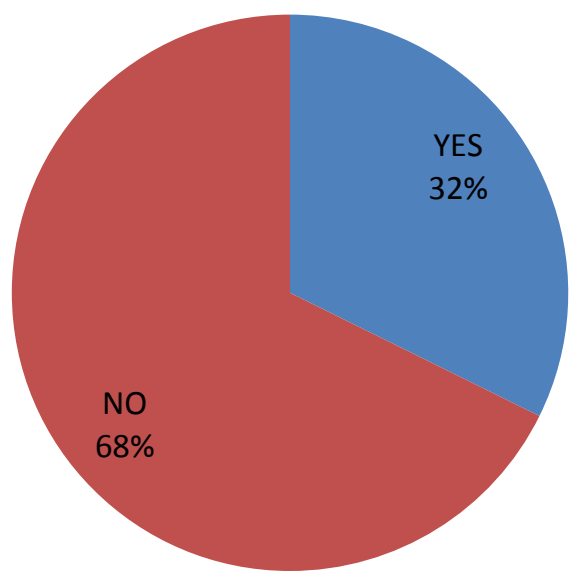

Figure 1: Prevalence of contraceptive use among KCNP students

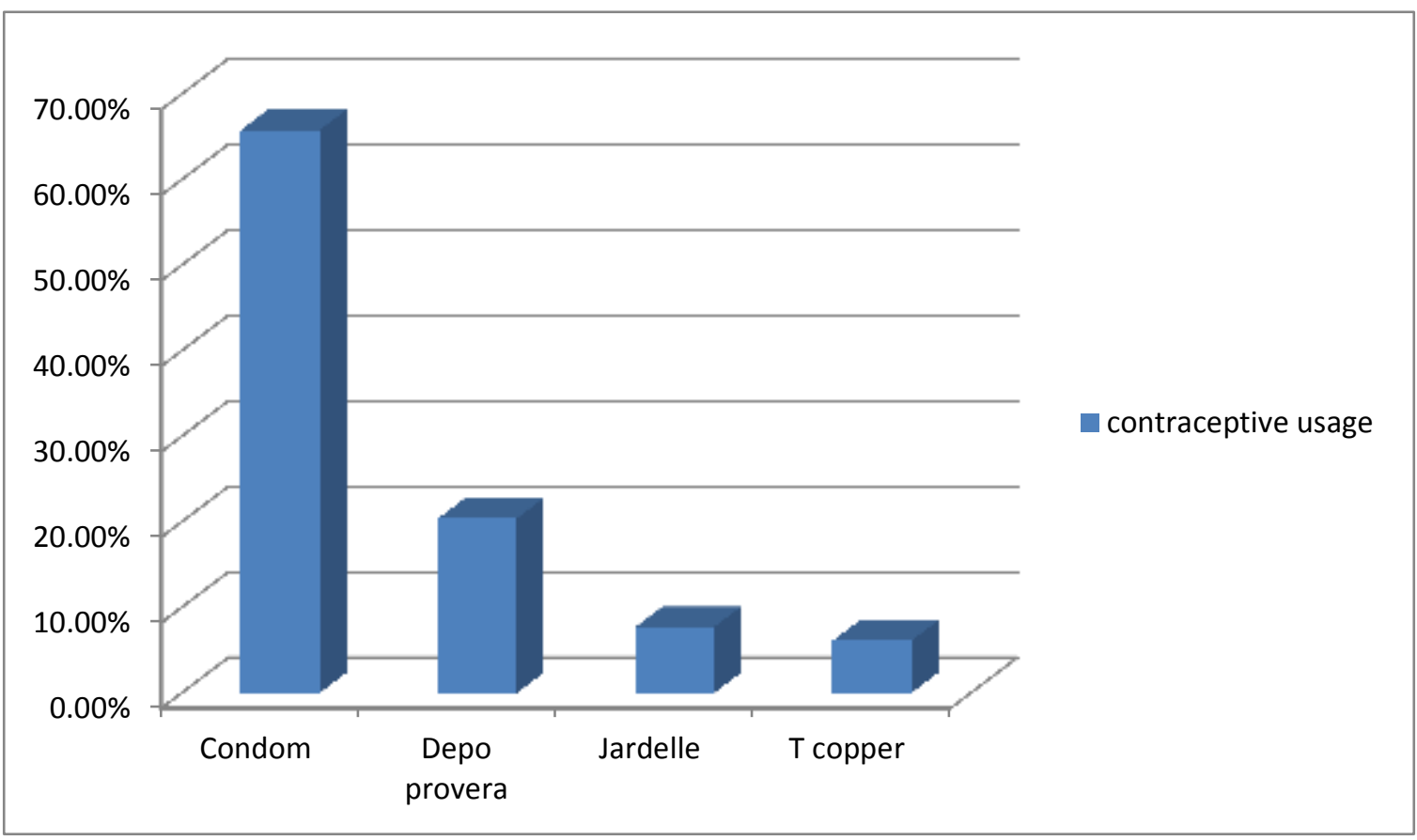

Figure 2: Preferred contraceptive among KCNP students 
TABLES

Table 1: Bivariate analysis on socio demographic factors

\begin{tabular}{|c|c|c|c|c|c|c|c|}
\hline \multirow[t]{2}{*}{ Variable } & \multirow[t]{2}{*}{ Category } & \multirow{2}{*}{$\begin{array}{c}\text { Frequency } \\
\mathrm{N}=196\end{array}$} & \multicolumn{2}{|c|}{ Contraceptive use } & Df & Chi & $P=$ value \\
\hline & & & On $(n=124)$ & Not $(n=72)$ & 1 & 1.906 & 0.167 \\
\hline \multirow[t]{2}{*}{ Age } & $18-20$ years & $142(72.4 \%)$ & $94(75.8 \%)$ & $48(66.7 \%)$ & & & \\
\hline & 21-24 years & $54(27.6 \%)$ & $30(24.2 \%)$ & $24(33.3)$ & & & \\
\hline \multirow[t]{2}{*}{ Religion } & Christian & $144(73.5 \%)$ & $95(76.6 \%)$ & $49(68.1 \%)$ & \multirow[t]{2}{*}{1} & \multirow[t]{2}{*}{2.422} & \multirow[t]{2}{*}{0.120} \\
\hline & Muslim & $52(26.5 \%)$ & $29(23.4 \%)$ & $23(31.9 \%)$ & & & \\
\hline \multirow[t]{3}{*}{ Course } & Certificate & $68(34.7 \%)$ & $60(48.4 \%)$ & $8(11.1 \%)$ & \multirow[t]{3}{*}{1} & \multirow[t]{3}{*}{35.403} & \multirow[t]{3}{*}{0.000} \\
\hline & Diploma & $118(60.2 \%)$ & $55(44.4 \%)$ & $63(87.5 \%)$ & & & \\
\hline & $\begin{array}{c}\text { Higher } \\
\text { diploma }\end{array}$ & $10(5.1 \%)$ & $9(7.2 \%)$ & $1(1.4 \%)$ & & & \\
\hline \multirow{3}{*}{$\begin{array}{l}\text { Level of pocket } \\
\text { money (Ksh.) }\end{array}$} & $<2000$ & $34(17.3 \%)$ & $20(16.1 \%)$ & $14(19.4 \%)$ & \multirow[t]{3}{*}{2} & \multirow[t]{3}{*}{6.738} & \multirow[t]{3}{*}{0.034} \\
\hline & $2000-5000$ & $94(48 \%)$ & $68(54.8 \%)$ & $26(36.1 \%)$ & & & \\
\hline & $>5000$ & $68(34.7 \%)$ & $36(29.1 \%)$ & $32(44.5 \%)$ & & & \\
\hline \multirow[t]{3}{*}{ Residence } & $\begin{array}{l}\text { College } \\
\text { hostels }\end{array}$ & $45(23 \%)$ & $37(29.8 \%)$ & $8(11.1 \%)$ & \multirow[t]{3}{*}{2} & \multirow[t]{3}{*}{99.521} & \multirow[t]{3}{*}{0.000} \\
\hline & $\begin{array}{c}\text { Home with } \\
\text { relatives }\end{array}$ & $62(31.6 \%)$ & $8(6.5 \%)$ & $54(75 \%)$ & & & \\
\hline & Rentals & $89(45.4 \%)$ & $79(63.7 \%)$ & $10(13.9 \%)$ & & & \\
\hline
\end{tabular}

Table 2: Bivariate analysis on student knowledge on contraceptive

\begin{tabular}{|c|c|c|c|c|c|c|c|}
\hline \multirow[t]{2}{*}{ Variable } & \multicolumn{2}{|c|}{ Category $(\mathrm{N}=196)$} & \multicolumn{2}{|c|}{ Contraceptives use } & \multirow[t]{2}{*}{ Df } & \multirow{2}{*}{$\begin{array}{c}\text { Chi } \\
\text { square }\end{array}$} & \multirow[t]{2}{*}{$P=$ value } \\
\hline & & & On $(n=124)$ & Not $(n=72)$ & & & \\
\hline \multirow[t]{2}{*}{ Aware of contraceptive } & Yes & $194(99 \%)$ & $123(99.2 \%)$ & $71(98.6 \%)$ & \multirow[t]{2}{*}{1} & \multirow[t]{2}{*}{0.153} & \multirow[t]{2}{*}{0.696} \\
\hline & No & $2(1 \%)$ & $1(0.8 \%)$ & $1(1.4 \%)$ & & & \\
\hline \multirow[t]{2}{*}{ Mode of action } & Yes & $3(1.5 \%)$ & $1(0.8 \%)$ & $2(2.8 \%)$ & \multirow[t]{2}{*}{1} & \multirow[t]{2}{*}{1.174} & \multirow[t]{2}{*}{0.278} \\
\hline & No & $193(98.5 \%)$ & $123(99.2 \%)$ & $70(97.2 \%)$ & & & \\
\hline \multirow[t]{2}{*}{ Indications } & Yes & $194(99 \%)$ & $122(98.4 \%)$ & $72(100 \%)$ & \multirow[t]{2}{*}{1} & \multirow[t]{2}{*}{1.173} & \multirow[t]{2}{*}{0.279} \\
\hline & No & $2(1 \%)$ & $2(1.6 \%)$ & $0(0 \%)$ & & & \\
\hline \multirow{2}{*}{ Side effects } & Yes & $80(40.8 \%)$ & $52(41.9 \%)$ & $28(38.9 \%)$ & \multirow[t]{2}{*}{1} & \multirow[t]{2}{*}{0.175} & \multirow[t]{2}{*}{0.676} \\
\hline & No & $116(59.2 \%)$ & 72(58.1\%) & $44(61.1 \%)$ & & & \\
\hline \multirow[t]{2}{*}{ Usage } & Yes & $112(57.1 \%)$ & $94(75.8 \%)$ & $18(25 \%)$ & \multirow[t]{2}{*}{1} & \multirow[t]{2}{*}{48.012} & \multirow[t]{2}{*}{0.000} \\
\hline & No & $84(42.9 \%)$ & $30(24.2 \%)$ & $54(75 \%)$ & & & \\
\hline \multirow[t]{2}{*}{ Storage } & Yes & $68(34.7 \%)$ & $50(40.3 \%)$ & $18(25 \%)$ & \multirow[t]{2}{*}{1} & \multirow[t]{2}{*}{4.720} & \multirow{2}{*}{0.030} \\
\hline & No & $128(65.3 \%)$ & $74(59.7 \%)$ & $54(75 \%)$ & & & \\
\hline \multirow[t]{2}{*}{ Effectiveness } & Yes & $172(87.8 \%)$ & $109(87.9 \%)$ & $63(87.5 \%)$ & \multirow[t]{2}{*}{1} & \multirow[t]{2}{*}{0.007} & \multirow[t]{2}{*}{0.974} \\
\hline & No & $24(12.2 \%)$ & $15(12.1 \%)$ & $9(12.5 \%)$ & & & \\
\hline
\end{tabular}


Table 3: Bivariate analysis on accessibility of contraceptive

\begin{tabular}{|c|c|c|c|c|c|c|c|}
\hline \multirow[t]{2}{*}{ Variable } & \multirow[t]{2}{*}{ Category } & \multirow{2}{*}{$\begin{array}{c}\text { Frequency } \\
(\mathrm{N}=196)\end{array}$} & \multicolumn{2}{|c|}{ Contraceptive use } & \multirow[t]{2}{*}{ Df } & \multirow{2}{*}{$\begin{array}{c}\text { Chi } \\
\text { square }\end{array}$} & \multirow[t]{2}{*}{$P=$ value } \\
\hline & & & Yes $(n=124)$ & No $(n=72)$ & & & \\
\hline \multirow{2}{*}{$\begin{array}{l}\text { Available at nearby } \\
\text { facility }\end{array}$} & Yes & $151(77 \%)$ & $103(83.1 \%)$ & $48(66.7 \%)$ & \multirow[t]{2}{*}{1} & \multirow[t]{2}{*}{6.925} & \multirow[t]{2}{*}{0.009} \\
\hline & No & $45(23 \%)$ & $21(16.9 \%)$ & $24(33.3 \%)$ & & & \\
\hline \multirow[t]{2}{*}{ Issued at college } & Yes & $65(33.2 \%)$ & $35(28.2 \%)$ & $30(41.7 \%)$ & \multirow[t]{2}{*}{1} & \multirow[t]{2}{*}{3.713} & \multirow[t]{2}{*}{0.054} \\
\hline & No & $131(66.8 \%)$ & $89(71.8 \%)$ & $42(58.3 \%)$ & & & \\
\hline \multirow[t]{2}{*}{ Availability at any time } & Yes & $58(29.6 \%)$ & $37(29.8 \%)$ & $21(29.2 \%)$ & \multirow[t]{2}{*}{1} & \multirow[t]{2}{*}{0.010} & \multirow[t]{2}{*}{0.921} \\
\hline & No & $138(70.4)$ & $87(70.2 \%)$ & $51(70.8 \%)$ & & & \\
\hline \multirow{2}{*}{$\begin{array}{l}\text { Parents support on } \\
\text { contraceptive use }\end{array}$} & Yes & $24(12.2 \%)$ & $13(10.5 \%)$ & $11(15.3 \%)$ & \multirow[t]{2}{*}{1} & \multirow[t]{2}{*}{0.974} & \multirow[t]{2}{*}{0.324} \\
\hline & No & $172(87.8 \%)$ & $111(89.5 \%)$ & $61(84.7 \%)$ & & & \\
\hline
\end{tabular}

\section{CONCLUSION}

Most college students at KCNP fall at an age range of 18-20 years, at this age most are sexually active and they need support from parents and institution on contraceptive choices. Their residence in college plays a role in sexual and contraceptive use practices

Majority of the respondents can access contraceptive products at a nearby health facility and which is significant to contraceptive uptake

The level of knowledge of on contraceptive use was satisfactory. However, uptake of contraceptive products was low despite the sexually active life by the students

\section{DISCUSSION}

The study findings shows that from a sample size of 196 respondents; about $142(72.4 \%)$ to be from an age range of 18-24 years, Christians were the dominant group with $144(73.5 \%)$ respondents and about $48 \%$ receive a monthly pocket money of Ksh. 2000 to 5000 . About $75 \%$ of the respondents are sexually active while prevalence of contraceptive use among the students was $32 \%$ and the preferred contraceptive being condom $(62 \%)$. Bivariate analysis findings shows that residence $(p=0.000)$ of the respondents was statistically significant to contraceptive use

Based on the student knowledge on contraceptives; about 144 (99\%) of the respondents are aware of contraceptives and 172(87.8\%) understand their effectiveness. However, there was decline in knowledge on side effects $(40.8 \%)$, storage $(34.7 \%)$ and mode of action of oral contraceptives (1.5\%). Bivariate analysis findings show that the knowledge on storage of contraceptives was statistically significant. Similar study findings have shown increased level of knowledge on use of emergence contraception are those with higher levels of education (Obi SN et al;
2008) those living in urban regions (Keeshury et al; 2011, Mbizhos and Zaid, 2010 and Chin Quee and Engle, 2000).

About 151(77\%) of the respondents access their contraceptives within a nearby facility like a hospital or community pharmacies, $65(33.2 \%)$ receive the contraceptives in college (condoms) and 172(87.8\%) of the respondents are using contraceptives without the knowledge of their parents. The bivariate analysis findings show that availability of contraceptives within a nearby facility $(\mathrm{p}=0.009)$ was significant to contraceptive use. Other studies show that it is becoming a trend where emergency contraceptives are moving from prescription to over the counter product easily available in a community pharmacy (Raymond et al; 2011, Coetaux and Pillsburry, 2000), and sold by pharmacists and pharmaceutical technologists (Brieger WR et al; 2004).

\section{RECOMMENDATIONS}

The study recommends on the following;

1. The institutions of higher learning and the parents need to support their children on sexual health in order to arrive at an equilibrium between sexual activity and contraceptive use which stands at $75 \%$ to $32 \%$

2. Despite the level of knowledge of contraceptives being high (99\%), there was need to educate the students on variety of contraceptive products, mode of action and safety

3. Institutions of higher learning should employ an health care worker who can ensure that there is always sustainable contraceptive commodities to students all times 


\section{REFERENCES}

1. Brieger WR,Osmor PE,Salami KK,Oladepo O,Otusanya SA (2004).Interaction between patent medicine vendors and customers in urban and rural Nigeria. Health policy plan; 19(3):77-82

2. Chin-Quee DS and Engle KL (2012). Frequency and context of EC use in urban Kenya and Nigeria, paper presented at EC Jambore2012, New York, Oct5, 2012.

3. Coeytaux $F$ and Pillsbury B, (2000). Bridging emergence contraception to American women: the history and remaining challenges, Women's Health issues, 11(2)80-86

4. Keesbury J, MorganG and Owino B (2011). Is repeat use of emergency contraception among pharmacy clients? Evidence from Kenya, contraception, 83(4):346-351.

5. Mbizho MT, Zaidi (2010). Addressing critical gaps in achieving universal access to sexual and reproductive health( $S R H)$.The case for improving adolescent SRH,preventing unsafe abortion, and enhancing linkages between SRH and HIV interventions.Int J Gynecol obstet, 110(0).S3-6.

6. Mugenda O. M\& Mugenda A.G (1999), "Research Methods; Quantitative and Qualitative Approaches," Africa Center for Technology Studies (ACTS) press, Nairobi Kenya

7. Obi SN and Ozumba BC (2008). Emergency contraceptive knowledge and practice among unmarried women in Enugu, southeast Nigeria, Nigerian journal of clinical practice, 11 (4):296-299

8. Raymond E Westley E and Trusell J (2011). Repeat use of emergency contraception in Kenya letter to the editor, contraception, 84(6):658-656

9. Sedgh G,Henshaw S,Singh S,Ahman E,Shah IH (2007). Inducxed abortion: estimated rates and trends worldwide.Lancet, 370(9595): 1338-45.

10. Singh S, Sedgh G, Hussain $R$ (2010). United pregnancy: worldwide levels, trends, and outcomes.

Stud Fam plan, 41(4):241-50.

11. WHO (2004).Marternal Mortality in 2000: Estimates developed by WHO, UNICEF, and organization; 2004

$$
\text { UNFPA.Geneva World Health }
$$

12. WHO (2012). From evidence to policy: Expanding Access to family planning optimizing the health work force for effective family planning services.Geneva:World health organization;2012. 